Research article

\title{
Rewetting in Mediterranean reclaimed peaty soils and its potential for phyto-treatment use
}

\author{
Vittoria Giannini ${ }^{\text {a, }}{ }^{\text {, }}$, Andrea Bertacchi ${ }^{\text {b }}$, Enrico Bonari ${ }^{a}$, Nicola Silvestri a \\ a Institute of Life Sciences, Scuola Superiore Sant'Anna di Studi Universitari e di Perfezionamento, Piazza Martiri della Libertà, 33, 56127, Pisa (IT), Italy \\ ${ }^{\mathrm{b}}$ Department of Agriculture, Food and Environment, Università di Pisa, Via del Borghetto, 80, 56124, Pisa (IT), Italy
}

\section{A R T I C L E I N F O}

\section{Article history:}

Received 2 August 2017

Received in revised form

4 December 2017

Accepted 8 December 2017

\section{Keywords:}

Phragmites

Myriophyllum

Phyto-treatment

UAV

Wetland vegetation

\begin{abstract}
A B S T R A C T
A pilot experimental field combining rewetting of reclaimed peaty soils and water phyto-treatment was set up in the Massaciuccoli Lake basin (Tuscany, Italy) to reduce the water eutrophication and peat degradation caused by almost a century of drainage-based agricultural use.

In this paper, we investigated the restoration process occurring consequently to the conversion of a drained area in a natural wetland system (NWS) (the partial top soil removal, the realization of a perimeter levee to contain the waters, the rewetting with the drainage waters coming from the of surrounding cultivated areas) and the capability of the spontaneous vegetation to catch nutrients acting as a vegetation filter.

To follow the restoration process over time (2012-2016), we used a mixed approach merging phytosociological surveys with ortophotos taken by an Unmanned Aerial Vehicle (UAV). During the last year of observation (2016), we performed destructive sampling on the most widespread plant communities in the area (Phragmites australis and Myriophyllum aquaticum community) to quantify the biomass production and the uptake of nitrogen and phosphorus.

Stands of Phragmites australis (Cav.) Trin. ex Steud. yielded more than Myriophyllum aquaticum (Vell.) Verdc. (4.94 kg m-2 vs $1.08 \mathrm{~kg} \mathrm{~m}-2$ ). M. aquaticum showed higher nutrient contents $(2.04 \%$ of $\mathrm{N}$ and $0.35 \%$ of $\mathrm{P}$ ), however $P$. australis was able to take up more nutrients within the NWS because of its larger cover and productivity.

In the perspective of maximizing the plant development and consequently the amount of nutrients extracted from treated waters, the authors suggest $4-5$ year-long-harvesting turns, better occurring in spring-summer.
\end{abstract}

() 2017 Elsevier Ltd. All rights reserved.

\section{Introduction}

Peatlands drainage and their following exploitation have severely compromised their ecological and biological status worldwide, because of the changes in the land use produced by agriculture, forestry and urbanization (Grootjans et al., 2012). We can estimate that nowadays less than $20 \%$ of the original, pristine wetland areas still remain (Verhoeven, 2014).

By altering groundwater patterns and compositions, extensive peatland drainage has determined significant changes on the physics and chemistry of peats, leading to: i) acceleration of organicmatter oxidation (Oleszczuk et al., 2008), with a consequent

\footnotetext{
* Corresponding author.

E-mail address: v.giannini@santannapisa.it (V. Giannini).
}

increase in greenhouse gases (GHG) emissions into the atmosphere of up to $25 \mathrm{t} \mathrm{CO}_{2}$ equivalent $\mathrm{ha}^{-1} \mathrm{y}^{-1}$ (Wichtmann and Wichmann, 2011; Couwenberg et al., 2011); (ii) enhancement of mineralization and nitrification of organic $\mathrm{N}$ due to higher oxygen availability and consequent increase of $\mathrm{NO}_{3}^{-}$concentrations in porewater (Tiemeyer et al., 2007) and (iii) mineralization of organic $\mathrm{P}$ compounds and increase of absorbed and Fe-bound $\mathrm{P}$ pools (Zak et al., 2004). The continual recurrence of these phenomena has negatively affected the status of peatlands, lowering the soil level (subsidence), increasing nutrient availability and loads delivered to receiving water bodies (eutrophication) and decreasing ecosystem biodiversity and functionality (loss of resilience) (Smolders et al., 2006; Pistocchi et al., 2012; Lamers et al., 2015).

Moreover, these deeply drained areas are becoming unsuitable for modern agricultural production requirements (Pfadenhauer and 
Grootjans, 1999) and almost inaccessible for the ordinary machines used in agriculture.

From a merely biodiversity perspective, peatlands are unique, complex ecosystems of global importance, since they contain many species found only or mainly in peatlands thanks to the water regime of these areas (Tanneberger and Wichtmann, 2011).

For all these above-mentioned factors considered, stopping the peatland drainage and planning the consecutive management represent an environmental priority to face.

From literature, we can derive that there are different reasons leading to the change by moving from the traditional drainagebased management of peatlands: stimulating the restoration of land portion deteriorated from prolonged drainage (e.g. restoring) or recovery of the agricultural productivity of the areas (e.g. paludiculture).

Regardless the aims behind the restoration, we can assume that to achieve the rehabilitation of at least some of the functions supplied by these ecosystems, two main conditions have to be met i) rewetting (e.g. constructing dams or filling in drainage ditches) and ii) reduction of trophic status (e.g. by mean of the top soil removal) (Van Dijk et al., 2007; Klimkowska et al., 2010a,b; Zak et al., 2014).

Both are not without side effects. Raising water level and flooding organic soils can lower the soil nutrient availability (mainly released as ammonium), but can at the same time boost phosphorus mobilization (Lamers et al., 2002; Meissner et al., 2008; Zak et al., 2004).

Top soil removal, i.e. the removal of the upper and most degraded peat layers responsible of the higher mobilization of phosphorous during the rewetting phase (Zak and Gelbrecht, 2007; Zak et al., 2017) causes the removal of the reproductive organs of plant species (seeds, stolons, rhizomes, etc.) (Lepš, 1999) delaying the time of re-naturation.

The case study reported in the present paper is linked to a project realized in Tuscany (IT), which compares three different management strategies aimed to combine the peatland rewetting and the water phyto-treating action.

In this paper, we focused on the Natural Wetland System (NWS). The first objective was to follow the restoration process after rewetting of lowlands to evaluate the dynamics driven by the reestablished vegetation. According to literature, the ecological restoration perspective is highly dependent on the zero-point condition before starting the restoration process (Klimkowska et al., 2010b). Indeed, while Tanneberger and Wichtmann (2011) report that top soil removal in combination with rewetting can lead to the restoration of soft-water pools and small sedge marshes within 5 years, Poschlod (1992) shows that in the case of peatland severely used for peat extraction mostly monospecific stands of non-peat-forming species could develop even for 20 years after the rewetting. Joosten (1995) even reports that in the cases of severe anthropogenic impact on the environment, it is not possible to observe any change within a human time perspective.

The second important research goal was to evaluate the capability of the NWS to work as phyto-treatment system thanks to the capability of plants to take up nutrients from waters proportionally to the biomass production and nutrient contents in the vegetative tissues.

\section{Material and methods}

\subsection{Site description}

The study was carried out over 5 years (2011-2016) in Vecchiano, about $10 \mathrm{~km}$ from Pisa, Italy (43 $49^{\prime} 59.5^{\prime \prime} \mathrm{N}$; $10^{\circ} 19^{\prime} 50.7^{\prime \prime}$ ) in the Migliarino, San Rossore, Massaciuccoli Natural Park, within a 15 ha experimental area (Fig. $1 \mathrm{a}$ and $\mathrm{b}$ ).

This site was used to compare the efficiency of three different strategies in treating the eutrophic drainage water coming from a cultivated sub-watershed within the reclamation district around the Massaciuccoli Lake. In this area, phosphorous has been recognized as the primary cause of the eutrophication and the losses of this nutrient from cultivated fields (dissolved + particulate fractions) are estimated in $2-4 \mathrm{~kg} \mathrm{ha}^{-1} \mathrm{y}^{-1}$ (Pensabene et al., 1997; Bonari et al., 2013).

The NWS was set up as natural rewetted area with a surface area of 2.7 ha and surrounded by small embankments built with the top soil $(\sim 10 \mathrm{~cm})$ removed long the area's borders. Natural elevation changes within the NWS helped in creating zones with a different bottom height in order to promote the colonization from a large variety of plant species.

The soils of this experimental area has been classified as Histosol according to the USDA system and as Rheic Histosol according to the FAO system (Pellegrino et al., 2015).

The climate is classified as Mediterranean (Csa) according to Köppen-Geiger climate classification map (Kottek et al., 2006). Summers are dry and hot, while rainfall is mainly concentrated in autumn and spring (mean annual rainfall $=910 \mathrm{~mm}$ ) and mean air

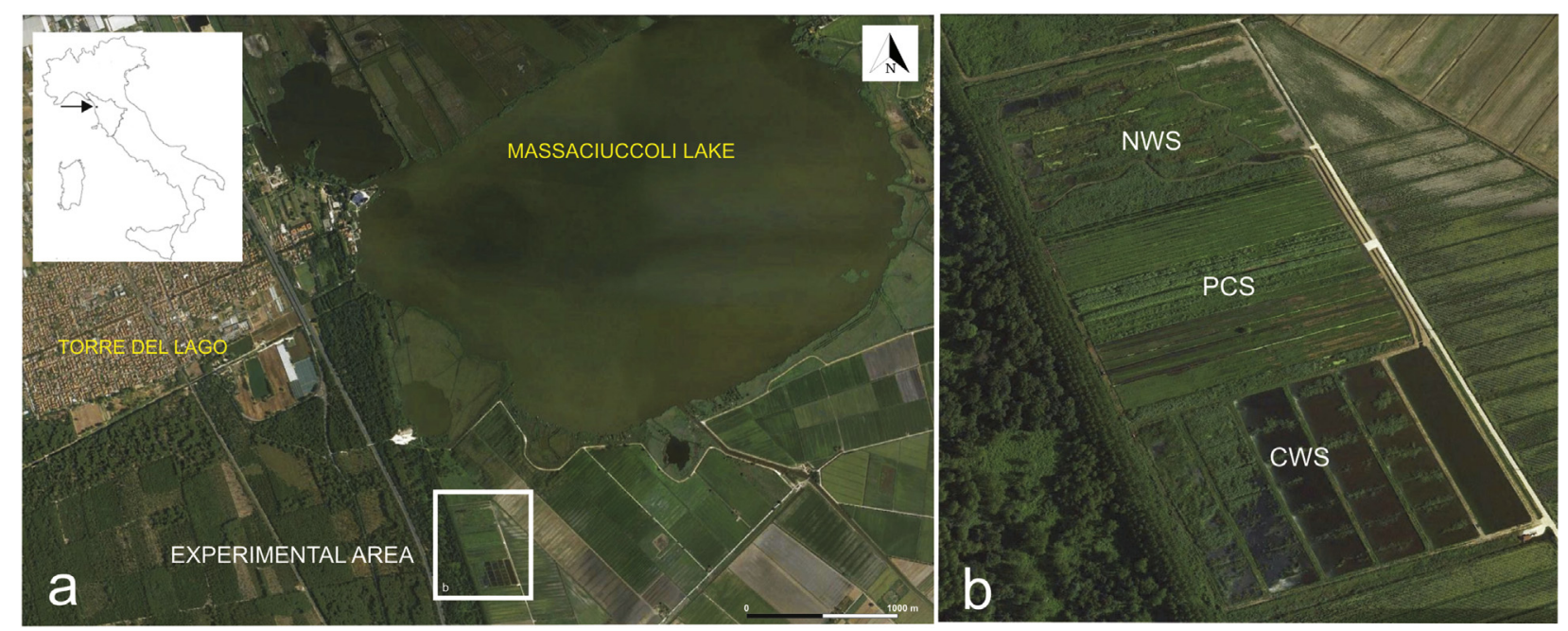

Fig. 1. (a) Aerial view of the Massaciuccoli Lake catchment (Tuscany, IT) and (b) zooming on the experimental area. 
temperature at $2 \mathrm{~m}$ ranges from $6.6{ }^{\circ} \mathrm{C}$ to $21.8{ }^{\circ} \mathrm{C}$ (mean $=14.6$ ). Mean monthly temperatures and rainfall for 2011-2016 were recorded at a weather station closed to the experimental site, located in Metato (San Giuliano T., 5 m a.s.l., 611370 E UTM, 4847363 N UTM).

The water level within the NWS was registered daily from December 2013 to August 2016. From January 2013 to November 2013, the system was not equipped with a diver (CTD-Diver produced by Schlumberger) for the water level measurement, thus manual measurements were performed every 15 days (Table 1 ).

The analyses of treated waters confirmed their eutrophic status with average annual total nitrogen content ranging from $7.14 \mathrm{mg} / \mathrm{L}$ to $8.13 \mathrm{mg} / \mathrm{L}$, the average annual total phosphorus content ranging from 0.24 to $1.07 \mathrm{mg} / \mathrm{L}$. About the soluble forms, the average annual Soluble Reactive Phosphorus (SRP) ranged between 0.15 and $0.22 \mathrm{mg} / \mathrm{L}$, while the average annual nitrates content varied from 1.41 to $3.23 \mathrm{mg} / \mathrm{L}$.

\subsection{Trial setup and vegetation analyses}

The construction works lasted two years (2011 and 2012) and in January 2013 the phyto-treatment system started to operate. The NWS's vegetation was periodically monitored from April 2013 up to July 2016. Every year, in spring-summer, vegetation development

Table 1

Mean water table levels for the different seasons over the years of observation. The reported values ( $\mathrm{h}$ in $\mathrm{mm}$ ) were measured relative to the weir $(\sim 25 \mathrm{~cm}$ above the NWS bottom level) at the outlet of the system.* is used to report period with water flow interruption for operation activities.

\begin{tabular}{lllll}
\hline \multicolumn{2}{l}{ Mean seasonal value: $\mathrm{h}(\mathrm{mm})$} & & \\
\hline & $\begin{array}{l}\text { Winter } \\
(\text { Dec-Feb) }\end{array}$ & $\begin{array}{l}\text { Spring } \\
\text { (Mar-May) }\end{array}$ & $\begin{array}{l}\text { Summer } \\
\text { (Jun-Aug) }\end{array}$ & $\begin{array}{l}\text { Fall } \\
\text { (Sep-Nov) }\end{array}$ \\
\hline 2013 & 50 & 55 & 38 & 65 \\
2014 & $38^{*}$ & $11^{*}$ & 45 & 83 \\
2015 & 76 & 66 & 76 & 70 \\
2016 & 94 & 114 & 84 & - \\
\hline
\end{tabular}

and phytocenotic diversity were surveyed using the BraunBlanquet method (Braun-Blanquet, 1979). 30 Relevés were performed on surfaces varying from 4 to $100 \mathrm{~m}^{2}$ depending on the typology of the plant community. The used nomenclature of the plants accords to Pignatti (1982) and Conti et al. (2005).

A multivariate analysis procedure using syntax software (Podani, 2001) was carried out for data in vegetation surveys. The matrix of 48 species $x 18$ surveys was analysed according to UPGMA cluster algorithm analysis, applying the coefficient of similarity of Bray-Curtis. During the monitoring period, NWS aerial photos were taken every summer by using a drone (Iris +, 3D Robotics) flying at $25 \mathrm{~m}$ of height and equipped with a camera (gopro hero $3+, 12$ Megapixel). To remove distortion and correct the image back to a rectilinear lens projection and to make photo mosaic, software Adobe Photoshop CC and Agistoft PhotoScan Professional Edition were used, respectively.

At the given altitude, the obtained resolution was $1.75630 \mathrm{~cm} /$ pixel. Each orthomosaic has been created by composing 340 pictures, with a resulting reprojection error varying between 0.81 pixels to 8.43 pixels, with an average error equal to 2.47435 pixels.

Aero photos were imported in GIS environment using Map Info ${ }^{\circledR}$ 10.1 for geo-referencing and mapping, with an undetectable georeferenced error.

The images were interpreted by assigning, manually, each digitized area to a specific phytosociological community (Fig. 2).

In July 2016, we performed a destructive sampling campaign aimed at the determination of the biomass production and nutrient concentration of the plant species grown within the NWS. The sampling plots were chosen on the basis of the vegetation map assembled after the flight of June 2016. For each mono-specific population with a coverage of nearly $100 \%$, we identified some representative plots to use for the sample collection. In particular, we identified 7 homogenous sampling areas for Phragmites australis (Cav.) Trin. ex Steud. and 3 for Myriophyllum aquaticum (Vell) Verd.(Fig. 2). Within each of these areas, we took 3 samples using a metal frame with an inner area of $1 \mathrm{~m}^{2}$. The biomass of $P$. australis was harvested above the water surface level, while in the case of

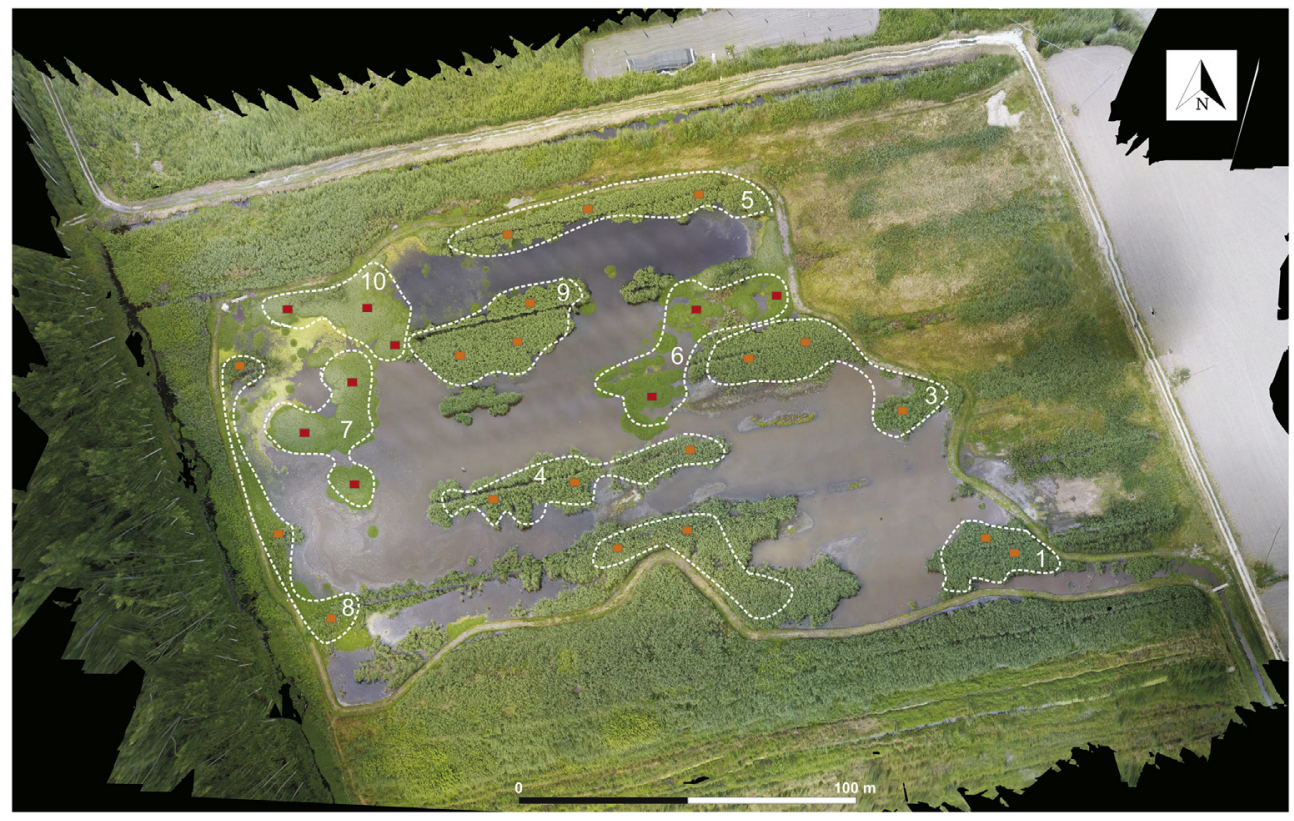

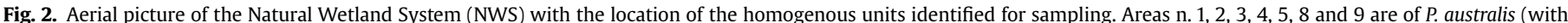

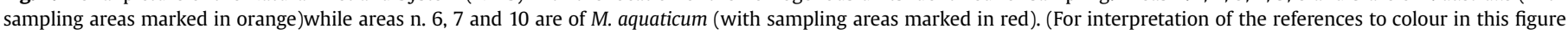
legend, the reader is referred to the Web version of this article.) 
M. aquaticum we took both the aerial and submerged parts (emergent shoots, stolons and submersed shoots), that is almost the whole plant biomass (Sytsma and Anderson, 1993). All sampling was done from a boat to minimize disturbance of the ecosystem.

For the determination of dry mass, samples were dried at $60{ }^{\circ} \mathrm{C}$ until reaching constant weight. To determine the composition of biomass, samples were finely milled with a Fritsch Pulverisette 14.

Nitrogen and Carbon concentration were measured with a CHNS Analyzer (Vario EL III - Elementar Analysessysteme Hanau Germany) through gas chromatography after dry combustion at $1150{ }^{\circ} \mathrm{C}$ (DIN EN 15104, 2010; DIN EN 14961-1, 2010). Phosphorus concentration was determined through photometrical determination (Murphy and Riley, 1962) after acidic digestion in a microwave digestion (EPA method n. 3052).

To validate the laboratory methods, a standard biomass of P. australis (Netherlands, BIMEP 412) was used (WEPAL, 2016).

The estimate of biomass production of the tested area (2.7 ha) was based on an upscaling process of the data collected at plot level. For both most represented mono-specific plant populations (P. australis and M. aquaticum, separately), we verified whether the mean production of each sampled areas were statistically different. Data were processed using the F-test in one-way ANOVA (version 9.1; SAS Institute Inc., Cary, NC, USA), with the homogeneous subareas as factors (groups) each of them replicated three times by using an elementary sampling area of about $1 \mathrm{~m}^{2}$. Two of the main assumptions of ANOVA (normal distribution and homogeneity of variance) were verified in this regard. The Duncan honest significant difference test was used for post-hoc means comparison at the $0.05 p$-level only when the differences among factors used to be significant.

Then, each statistically different value of biomass production per unit area was multiplied by the respective cover surface, so to obtain the contribution of two species to the total plant biomass production of NWS. The other cover types were not considered because they were either non-productive (uncovered area), or too little extended (Typha latipholia), or several species mixed (wet meadow).

The $\mathrm{N}, \mathrm{P}$ and $\mathrm{C}$ concentration of $P$. australis and $M$. aquaticum were transformed in arcsine to fulfil the assumptions of ANOVA and processed as described above.

Nutrient uptake $\left(\mathrm{kg} \mathrm{ha}^{-1}\right)$ was calculated as the product of nutrient concentration (nitrogen, phosphorus) and dry biomass weight.

\section{Results}

\subsection{Flora and vegetation}

The multivariate analysis on the data of the most representative phytosociological relevès ( $n .18$ ) led to the identification of four plant communities: 1- Phragmites australis community, 2- Myriophillum aquaticum community, 3- Typha latifolia community, 4wet meadows (Table 2, Fig. 3).

Floristic traits and physiognomic aspects confirmed the equipollence between the surveyed vegetation and the phytocoenosis widely spread on the neighbouring Massaciuccoli Lake (Bertacchi et al., 2015) and on the lacustrine areas of Tuscany, as well as described by Tomei et al. (1997). The first three communities are referable to Phragmition communis Koch 1926. The serial stage still in progress of wet meadow (which has been surveyed only from June 2014), did not allow us to reach a reliable assignment.

\subsection{Photointerpretation and vegetation mapping}

The ortophotos taken from the drone and re-organized one next to the other to recompose the whole area, allowed us to draw the development dynamics of the four above-cited plant communities over time (Fig. 4).

The implementation of the reconstructed photographic mosaic in GIS and the processing of digital data provided useful information about the fluctuations of the spatial pattern for the identified plant communities (Fig. 5).

In Fig. 5, the trends from 2012 to 2016 are reported. The area covered by $T$. latifolia was the lowest and almost stable in time (average $0.03 \mathrm{ha}$ ), while the area covered by wet meadow was, on average, the largest even if with wide fluctuations among the years (2.30 ha in 2013, 0.60 ha in 2014, 0.02 ha in 2015 and 0.16 ha in 2016). The $M$. aquaticum pointed out a significant increase of the covered surface between 2013 and 2015 (from 0.04 ha to 0.70 ha), whereas it has been more than halved in the last year ( $0.34 \mathrm{ha})$. The development of the P. australis showed the shortest variations over time, increasing from 0.60 to 0.96 ha in the 2013-2015 period and drawing a little contraction in 2016 ( 0.78 ha).

Overall, the total area covered by vegetation decreased from 2.24 ha in 2013 , to 1.82 ha in 2014 , to 1.68 ha in 2015 up to 1.30 ha in 2016.

\subsection{Biomass production and nutrients uptakes}

The execution of the Saphiro-Wilk and Bartlett tests confirmed that the biomass production data were normally distributed (W $=0.967$ and $\mathrm{W}=963$ for $P$. Australis and M. aquaticum, respectively) and their variances were homogeneous ( $\mathrm{p}>\chi^{2}=0.465$ and $\mathrm{p}>\chi^{2}=0.295$ for $P$. Australis and M. aquaticum, respectively). Then we proceeded rightly to ANOVA analysis (Table 3, Table 4).

$P$. australis growth was statistically homogeneous within the NWS' embankments and we did not find significant differences among the identified sub-areas. The overall mean production was equal to $4.94 \pm 1.67$ (standard deviation) $\mathrm{kg} \mathrm{m}^{-2} \mathrm{~d}$. m. (dry matter) and the values from the different sub-areas ranged from $3.15 \mathrm{~kg} \mathrm{~m}^{-2} \mathrm{~d}$. m. (sub-area 4) to $6.44 \mathrm{~kg} \mathrm{~m}^{-2} \mathrm{~d}$. m. (sub-area n.9).

$M$. aquaticum was less productive than $P$. australis with a mean production of $1.05 \pm 0.35$ (s.d.) $\mathrm{kg} \mathrm{m}^{-2} \mathrm{~d}$. $\mathrm{m}$. (weighted on the surface of each sub-areas). The sub-area $7\left(1.43 \mathrm{~kg} \mathrm{~m}^{-2} \mathrm{~d} . \mathrm{m}\right.$.) was significantly more productive than the other two (sub-areas 6 and 10) that were statistically equivalent between them $(0.80$ and $0.91 \mathrm{~kg} \mathrm{~m}^{-2} \mathrm{~d}$. m., respectively).

To estimate the biomass production within the NWS, we calculated the product of the mean production by the value of the corresponding area. Thus, we used the overall sample mean and the total surface occupied by $P$. australis, whereas we used the means of the sub-area 7 and the sub-areas 6 and 10 multiplied by the respective surface values, in the in the case of $M$. aquaticum.

Summing up the biomass production from each homogenous area as described above, we obtained a total biomass production of 38.54 tons d. m. for $P$. australis and of 3.56 tons d.m. for M. aquaticum deriving from an occupied surface equal to 0.78 ha and 0.34 ha, respectively.

About macronutrient content in biomass, there was not a significant difference in the nitrogen and phosphorous concentrations among the different sub-areas for both species.

In $P$. australis, the detected values ranged between $1.55 \%$ and $2.03 \%$ for nitrogen and between $0.14 \%$ and $0.19 \%$ for phosphorous, whereas in M. aquaticum the nutrients concentrations were higher varying from 1.88 to $2.20 \%$ for nitrogen and from 0.30 to $0.44 \%$ for phosphorous. 
Table 2

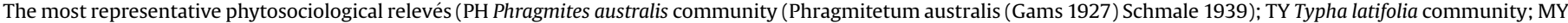

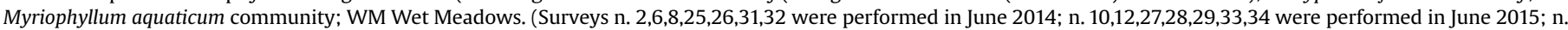
$13,14,30,35$ were performed in June 2016) (note: for index values, refer to the literature).

survey $n^{\circ}$

Surface (sq)

Coverage (\%)

Species $n^{\circ}$

$\begin{array}{llllcccccccccccccc}\mathbf{2} & \mathbf{6} & \mathbf{8} & \mathbf{1 0} & \mathbf{1 2} & \mathbf{1 3} & \mathbf{1 4} & \mathbf{2 5} & \mathbf{2 6} & \mathbf{2 7} & \mathbf{2 8} & \mathbf{2 9} & \mathbf{3 0} & \mathbf{3 1} & \mathbf{3 2} & \mathbf{3 3} & \mathbf{3 4} & \mathbf{3 5} \\ 25 & 25 & 25 & 25 & 25 & 25 & 25 & 9 & 9 & 4 & 60 & 100 & 100 & 25 & 25 & 25 & 25 & 25 \\ 100 & 100 & 100 & 100 & 100 & 100 & 100 & 80 & 80 & 100 & 80 & 80 & 100 & 50 & 70 & 80 & 100 & 100 \\ 6 & 3 & 6 & 6 & 7 & 5 & 5 & 4 & 6 & 3 & 5 & 5 & 2 & 10 & \mathbf{1 2} & 11 & 7 & 10\end{array}$

PH

TY

MY

WM

Phragmites australis (Cav.) Trin.

Calystegia sepium (L.) R.Br.

Eupatorium cannabinum L.

Stachys palustris L.

Lythrum salicaria $\mathrm{L}$.

Typha latifolia L.

Schoenoplectus tabernaemontani

(Gmel.) Palla

Mentha aquatica $\mathrm{L}$.

Iris pseudacorus L.

Oenanthe aquatica $\mathrm{L}$.

Apium nodiflorum (L.) Lag

Myriophyllum aquaticum (Vell). Verdc.

Juncus articulatus L.

Lemna minor $\mathrm{L}$.

Echinochloa crus-galli (L.) P. Beauv.

Poa trivialis $\mathrm{L}$.

Juncus effusus L.

Juncus bufonius L.

Carex otrubae Podp

Paspalum dilatatum Poir.

Ranunculus sceleratus L.

Ranunculus sardous Crantz

Samolus valerandi $\mathrm{L}$.

Epilobium hirsutum L.

\begin{tabular}{|c|c|c|c|c|c|c|c|c|c|c|c|c|c|c|c|c|}
\hline 4 & 5 & 5 & 4 & 4 & 4 & 4 & 1 & 1 & $\cdot$ & . & . & . & 1 & + & 2 & 1 \\
\hline+ & + & + & + & + & + & + & + & + & 1 & . & . & . & + & + & + & + \\
\hline . & . & . & + & + & + & . & . & . & . & . & . & . & . & $r$ & . & . \\
\hline . & . & + & + & + & . & . & . & . & . & . & . & . & . & . & . & . \\
\hline+ & . & . & + & + & . & $r$ & + & 1 & . & + & + & . & + & + & 2 & + \\
\hline . & $r$ & $r$ & . & . & . & . & 3 & 2 & 4 & . & $r$ & + & . & . & . & . \\
\hline
\end{tabular}

The largest differences between the two species were observed on the phosphorous concentration whose mean concentration was equal to $0.17 \% \pm 0.04$ (s.d.) in P. australis and $0.35 \% \pm 0.09$ (s.d.) in M. aquaticum. The mean concentrations of the two species were quite close in the case of nitrogen, although $M$. aquaticum showed again the higher values with $2.04 \% \pm 0.29$ (s.d.) against $1.79 \% \pm 0.21$

The nutrients taken up per unit area were equal to $882 \mathrm{~kg} \mathrm{ha}^{-1}$ of $\mathrm{N}$ and $84 \mathrm{~kg} \mathrm{ha}^{-1}$ of $\mathrm{P}$ for $P$. australis and $220 \mathrm{~kg} \mathrm{ha}^{-1}$ of $\mathrm{N}$ and $38 \mathrm{~kg} \mathrm{ha}{ }^{-1}$ of $\mathrm{P}$ for $M$. aquaticum. From these data, we can derive (s.d.) of $P$. australis.

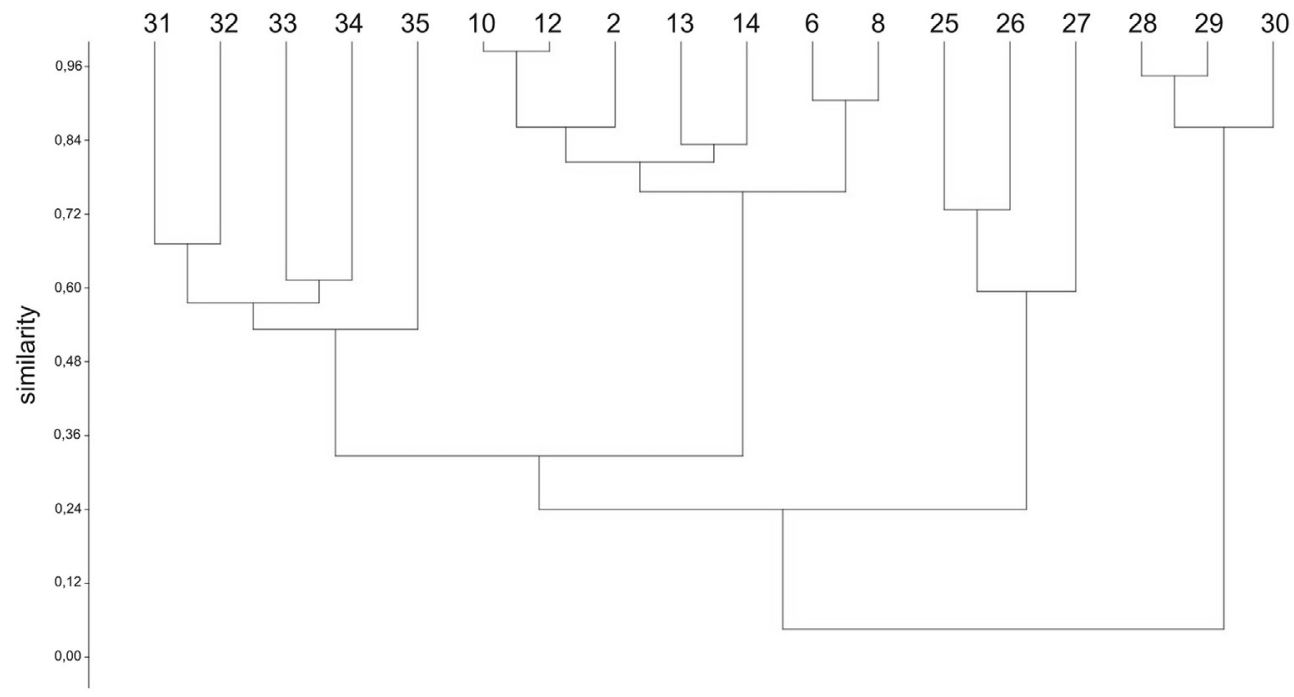

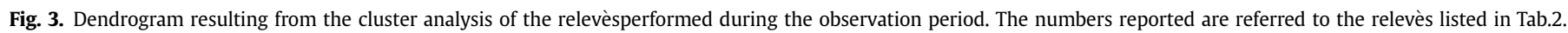



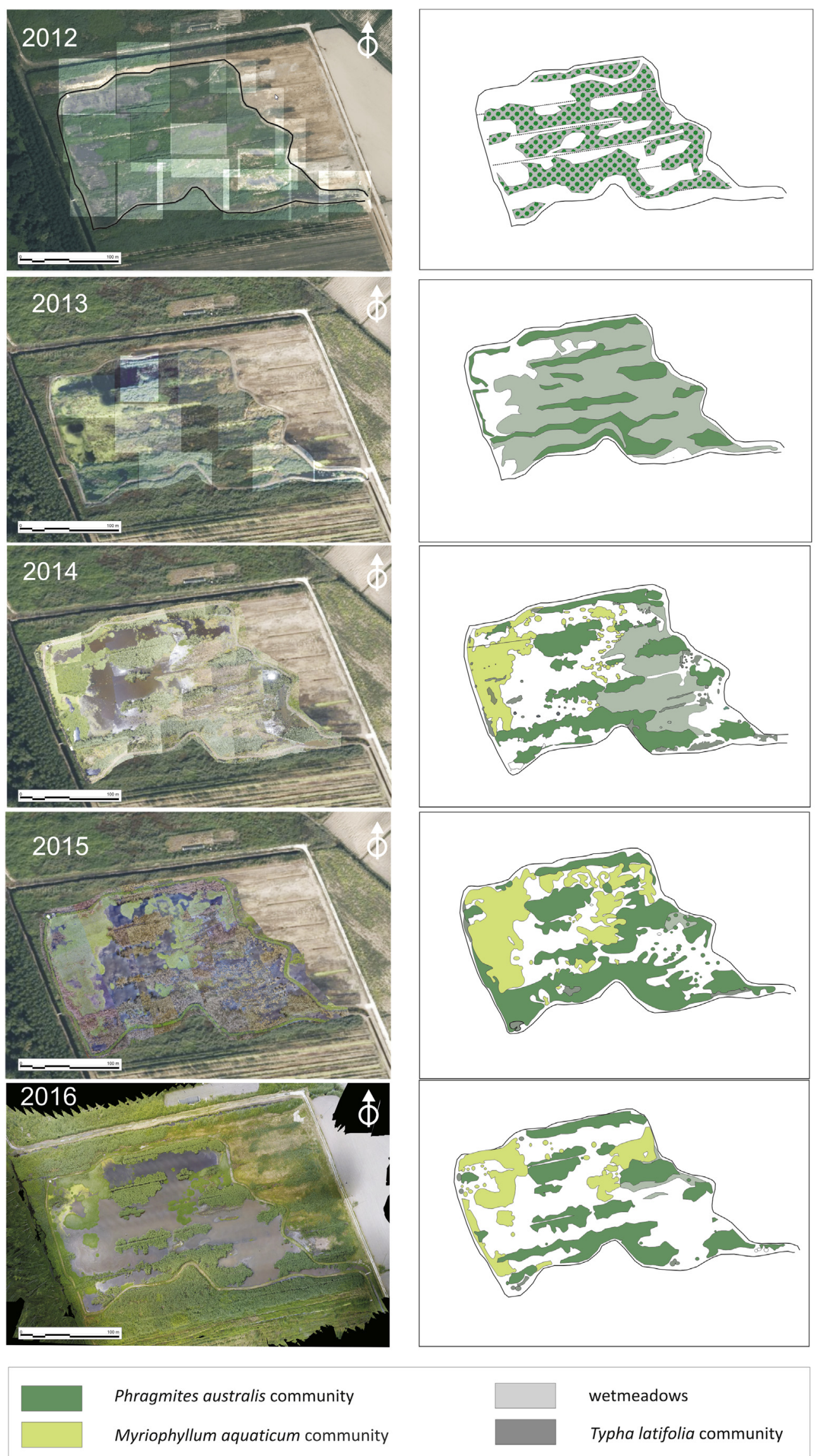

Phragmites australis community

Myriophyllum aquaticum community

wetmeadows

Typha latifolia community

Fig. 4. The diachronic mosaic of the vegetation succession of the NWS from 2012 to 2016. On left hand, the reconstruction from the ortophotos; on right hand, the sketch reporting the surface covered by each community year by year. The analysis reported is referred only to summer flights. 


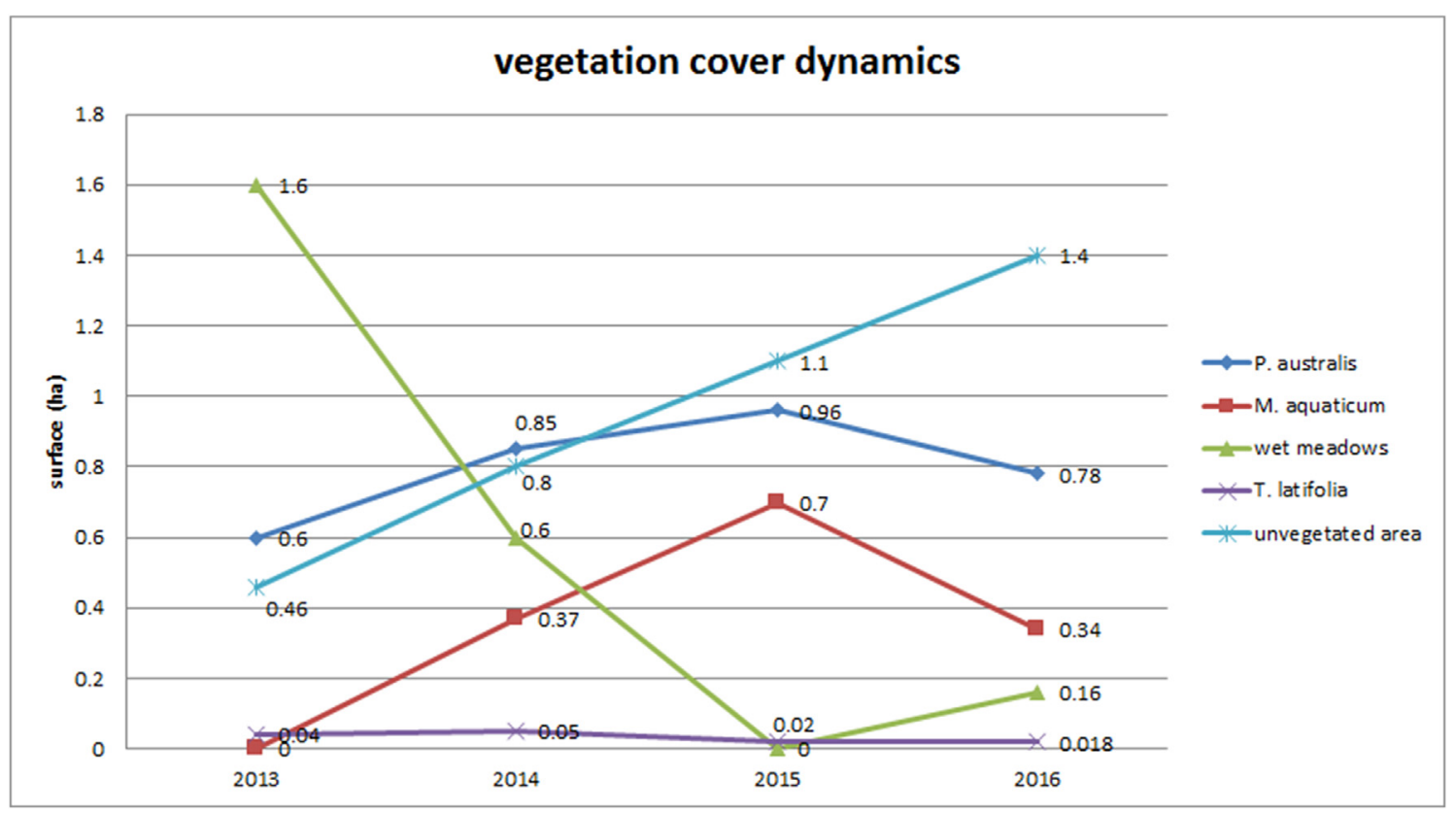

Fig. 5. Fluctuation of the cover values reached by different communities from 2013 to 2016 .

Table 3

Results of ANOVA on the P. australis parameters. Within each factor, means in the same column followed by different letters are significantly different at $\mathrm{p}<0.05$ (Duncan test).

\begin{tabular}{llll}
\hline Treatments & Biomass $\left(\mathrm{kg} \mathrm{m}^{-2}\right)$ d.m. & $\mathrm{N}$ content $(\%)$ & $\mathrm{P}$ content $(\%)$ \\
\hline Subarea 1 & 4.77 & 1.96 & 0.16 \\
Subarea 2 & 4.77 & 1.87 & 0.16 \\
Subarea 3 & 5.75 & 2.03 & 0.19 \\
Subarea 4 & 5.01 & 1.76 & 0.19 \\
Subarea 5 & 3.15 & 1.55 & 0.14 \\
Subarea 8 & 4.64 & 1.61 & 0.17 \\
Subarea 9 & 6.44 & 1.77 & 0.18 \\
& $\mathrm{p}=0.3692$ & $\mathrm{p}=0.4449$ & $\mathrm{p}=0.5055$ \\
\hline
\end{tabular}

Table 4

Results of ANOVA on the M. aquaticum parameters. Within each factor, means in the same column followed by different letters are significantly different at $p<0.05$ (Duncan test).

\begin{tabular}{llll}
\hline Treatments & Biomass $\left(\mathrm{kg} \mathrm{m}^{-2}\right)$ d.m. & N content $(\%)$ & P content $(\%)$ \\
\hline Subarea 6 & $0.91 \mathrm{~b}$ & 2.20 & 0.44 \\
Subarea 7 & $1.43 \mathrm{a}$ & 1.88 & 0.30 \\
Subarea 10 & $0.80 \mathrm{~b}$ & 2.05 & 0.30 \\
& $\mathrm{p}=0.0378$ & $\mathrm{p}=0.1759$ & $\mathrm{p}=0.0669$ \\
\hline
\end{tabular}

that the total nitrogen taken up from the spontaneous vegetation growing within the NWS was $761 \mathrm{~kg}$, of which $688 \mathrm{~kg}$ taken up from $P$. australis (90\%) and the remaining $73 \mathrm{~kg}$ taken up from M. aquaticum (10\%).

About phosphorus, P. australis contributed to take up $65 \mathrm{~kg}(83 \%$ of the total) while M. aquaticum to $13 \mathrm{~kg}$ (17\% of the total).

\section{Discussion}

\subsection{Vegetation response to rewetting}

From six years of observation, we can derive that the water level rising was successful in fostering the development of hydrohygrophilous species (Table 2). Moreover, the species found were equal to with those of the lacustrine ecosystems nearby in the Lake.
A critical phenomenon was the significant development of M. aquaticum. This exotic species of South American origin, is considered invasive in Italy and can pose a threat to other hydrophitic indigenous communities (Lastrucci et al., 2005). In our case, the species was already present in the Massaciuccoli Lake area and was subsequently penetrated the NWS system.

About the vegetation, it was evident the predominance of the hygrophylous phytocoenosis, which showed a quick renaturation process, as evidenced by the wide surface covered by the different plant communities.

The spatial distribution of the vegetation species within the area showed the prevalence of the T. latifolia on the borders or in the strips surrounding the central nucleus of NWS system colonized by the $P$. australis population because of its higher competitive ability as reported by many authors (Findlay et al., 2002; Meyerson et al., 2002), especially under eutrophic conditions.

The presence of a permanent water layer $(30-35 \mathrm{~cm})$ upon the buttom could justify the large distribution of $P$. australis and M. aquaticum within the NWS system. These species can prevail for long time and limit the development of other plants, which are not helophytes or are not provided with aerenchyma.

This behavior seemed to be proved by the wet meadows development that was largely widespread at the beginning of the re-naturation process ( 1.60 ha in 2013 and 0.60 ha in 2014) up to disappear almost completely in 2015 ( 0.02 ha). The partial recovery made in 2016 ( $0.16 \mathrm{ha}$ ) was to be related only with the temporarily drying up of some portions of the NWS (mostly occurred nearby the borders) that determined the regression of $P$. australis and M. aquaticum communities.

After an initial increase, the stabilization of the communities of $P$. australis and M. aquaticum, occurred in 2016, can be considered the result of their different ecological requirements, specific competitiveness and environmental conditions. Indeed $P$. australis is a rhizomatous helophyte, that needs to keep the overwintering buds under water but, for a part of the year, prefers to be in almost dry condition. In our case, the permanent flooding may have favored the hydrophytes as M. aquaticum, which spread in almost all the free spaces. 
Although the situation monitored in 2016 is far from stable and we can expect continuous variations in the area covered by $P$. australis and M. aquaticum, it is reasonable to suppose that these will remain the two most important mono-specific plant populations within the NWS. Only the occurrence of no-ordinary disturbances (e.g. harvest, drought, fire) will be able to modify significantly the current vegetation cover to favor the development of others plant association types such as wet meadows or T. latifolia.

\subsection{Photointerpretation and vegetation mapping}

The mixed investigation method proposed, based on the merging of field surveys and remote sensing data, was particularly useful for the identification of the vegetation dynamics following a renaturation process. It seemed to be promising since it permitted the integration of methods acting on different scale (Klančnik et al., 2015) by combining the accuracy of a field level survey (repeatability and the detectability) with the capability of remote sensing to extend the monitoring over huge areas (Stroh and Hughes, 2010). Moreover, the proposed method was rather simple to use and it did not require the purchase of expensive devices or sophisticated skills in computer science or drones management.

\subsection{Biomass production and nutrients uptakes}

The high productivity of Phragmites australis (4.94 $\mathrm{kg} \mathrm{m}^{-2}$ d.m.) was the effect of a series of favorable conditions such as abundant water, high incident radiation, favorable growth temperatures, highly nutrient availability and the sampling time choice (coincident with the highest biomass productivity) as it is also confirmed by several studies conducted in unlimited nutrients availability.

For example, Hocking (1989) registered $9.89 \mathrm{~kg} \mathrm{~m}^{-2} \mathrm{~d}$. m. at the peak of productivity in a nutrient-enriched swamp in inland Australia. Gopal and Sharma (1982) reported production ranging from 7.50 to $9.30 \mathrm{~kg} \mathrm{~m}^{-2} \mathrm{~d}$. $\mathrm{m}$. in nutrient enriched wetlands in India, while more recently Eid et al. (2010) showed a production of about $5.40 \mathrm{~kg} \mathrm{~m}^{-2} \mathrm{~d}$. m. in Egypt (Burullus Lake), data which are quite similar to our average production.

In conditions of limited nutrient availability, the production of $P$. australis are definitely lower as reported in literature: Asaeda et al. (2002) up to $1.03 \mathrm{~kg} \mathrm{~m}^{-2} \mathrm{~d}$. m. in Austria; Karunaratne et al. (2003) $1.98 \mathrm{~kg} \mathrm{~m}^{-2} \mathrm{~d}$. m. in Japan and Asaeda et al. (2006) $0.69 \mathrm{~kg} \mathrm{~m}^{-2} \mathrm{~d}$. m. in Japan.

Also for Myriophyllum aquaticum, mentioned in literature as parrot feather, many studies confirmed a positive correlation between relative growth rate and nutrient availability (Hussner et al., 2008). However the average yield we registered $\left(1.08 \mathrm{~kg} \mathrm{~m}^{-2} \mathrm{~d} . \mathrm{m}\right.$.) was lower than that reported by Shibayama (1988) $\left(2.80 \mathrm{~kg} \mathrm{~m}^{-2} \mathrm{~d}\right.$. m., assuming a fresh weight/dry weight ratio equal to 0.21 ) or by Monteiro and Moriera (1990) (about $4.60 \mathrm{~kg} \mathrm{~m}^{-2} \mathrm{~d}$. m.), whereas are comparable with that registered by Sytsma and Anderson (1993) for a Californian experiment (about $1 \mathrm{~kg} \mathrm{~m}^{-2} \mathrm{~d}$. m.).

These considerations, matched with the results of ANOVA, suggested that $P$. australis found favorable condition for its grown everywhere within the NWSs area, whereas $M$. aquaticum was penalized in some sub-areas and it could not reach a full productivity level. At this regard, we can speculate that the lower production of sub-areas 6 and 10 were due to the higher shading produced by $P$. australis, which colonized the nearest sub-areas.

In consideration of the phyto-treatment purpose attributed to the restoration process, the capability of the plants of taking up nutrients from waters and storing them in their tissues can play an important role in determining the efficacy of this option. This feature is extremely important for phosphorus, for which the plant accumulation and subsequent harvesting can represent an effective way to cut down the nutrient loads in the treated waters. Differently, the role played by plants in nitrogen removal is less reliable in consideration of the losses of $\mathrm{N}$ through a gaseous phase (Vymazal, 2007).

In our study, the mean amount of nutrients removed were high for P. australis ( $882 \mathrm{~kg} \mathrm{~N} \mathrm{ha}^{-1}$ and $84 \mathrm{~kg} \mathrm{P} \mathrm{ha}^{-1}$ ) and although lower, as well remarkable also for M. aquaticum $\left(\sim 220 \mathrm{~kg} \mathrm{~N} \mathrm{ha}^{-1}\right.$ and $\sim 38 \mathrm{~kg} \mathrm{P} \mathrm{ha}{ }^{-1}$ ).

These quantities can be considered not so significative if compared with the nutrient loads which are delivered each year to the NWS $\left(\sim 1700 \mathrm{~kg} \mathrm{~N}^{-1} \mathrm{y}^{-1}\right.$ and $\sim 130 \mathrm{~kg} \mathrm{P} \mathrm{ha}^{-1} \mathrm{y}^{-1}$, by considering 365 days of working per year, data not published), but there are some considerations that can deepen the real contribution of the plants in the nutrient abatement through the NWS.

The first point concerns the development cycle of $P$. australis under natural growing conditions. Since no harvests were foreseen, inevitably a portion of nutrients up taken by plants was in the litter and residues fallen during fall-winter period. Indeed, as reported in literature (Granéli, 1984), leaves losses in P. australis contribute to reduce the total plant biomass of $28 \%$ (from summer to winter). This value was also confirmed by results published by Giannini et al. (2016, 2017).

Although the fate of these nutrients is uncertain, it is presumable that they remain immobilized within the organic compounds for long time because of the anoxic condition that the plant residues found on the NWS's bottom when they are not undergone to a chemical-physical stabilization through peat-forming process. Thus, we should add to the amount of nutrient removed by NWS plants also the nutrients that has been taken up in the previous years and translocated in the plant portions left on the NWS bottom.

In our case study, harvesting during summer 2016 would have meant the removal of the yearly biomass produced by the reedbed during the 4th growing season while the previous annual productions were lying under the water layer. A gross quantification of the biomass produced during the previous 3 years can be tried multiplying the area covered by $P$. australis by the mean productivity registered during summer 2016, from which we estimate about 120 tons of dry biomass produced and not harvestable.

If this biomass presented the same average nutrient concentration detected in the biomass sampled in 2016, we could estimate about 2 tons of nitrogen and $200 \mathrm{~kg}$ of phosphorus taken up by the plant and largely fated to likely stabilization processes.

About M. aquaticum, Wersal and Madsen (2011) reported the strict connection existing between biomass production and nutrient availability, in particular the biomass is greater with at a high $\mathrm{N} / \mathrm{P}$ ratio, which was also our case $(\mathrm{N} / \mathrm{P}=10)$. The negative relationship between yield and $\mathrm{P}$ concentration according to Wersal and Madsen (2011) could be explained with an increased competition for light and nutrients with algae.

In our case study, $M$. aquaticum registered a very high nutrients concentration per unit of dry biomass, which made it competitive with $P$. australis in term of nutrient uptake although the biomass production was definitely lower.

We can estimate a previous productivity of about 11 tons of dry biomass produced and not harvested, containing about $230 \mathrm{~kg}$ of total nitrogen and $40 \mathrm{~kg}$ of total phosphorus.

Comparing the overall estimated production on four-year perspective with the nutrient loads, we could access that the phyto-treatment capability of the 'plant system' raised up to $15 \%$ for total nitrogen and 20\% for total phosphorus.

From a management perspective of NWS, an important point is related to the option of vegetation harvesting and thus, the effect that harvest time/cycle could have on the life span of the stands, on 
their productivity and their capability to take up nutrients. From the comparison with $P$. australis cultivated within the paludiculture system (PCS) (Giannini et al., 2017), we can derive some considerations. Indeed, while in NWS $P$. australis was unmanaged, in PCS was harvested every summer. This choice determined yield levels very different between the two systems. The production of 2016 was equal to $2.63 \mathrm{~kg} \mathrm{~m}^{-2} \mathrm{~d}$.m. for the PCS (unpublished data) versus $4.94 \mathrm{~kg} \mathrm{~m}^{-2} \mathrm{~d}$.m. for the NWS. Many authors reported a depressive effect of the summer harvest on P. australis, since the beds have not yet translocated all resources to rhizomes to guarantee a vigorous re-sprout in the next vegetative season (Granéli, 1990; Thompson and Shay, 1985). Moreover, recurrent mowing in flooded areas may amplify the negative effects of an early cut on productivity due to impaired convective ventilation and hypoxia on the basal part of the reed stands (Rolletschek et al., 2000).

Despite the large nutrient availability, we can derive that the adoption of the PCS' harvest strategy could determine in NWS a reduction of the growth potential of the reedbed especially in the first years of growing when the crop stand does not have a wellestablished underground reserve organs yet. After this phase, the annual cutting could increase the $P$. australis growth not only because the removal of dead culms favors the light interception by the new culms but also because the leaves, which are the organs photosynthetically active, are already completely lost (Granèli, 1989).

Thus, to maximize the phyto-treatment potential of the NWS, the best solution to adopt has can be a well-balanced harvest strategy by mowing $P$. australis every two years during summertime, after an initial phase of 4-5 unharvested years. In this way, we can favor the plant settlement without reducing significantly the reedbed life span (Güsewell et al., 2000).

In addition, the phyto-treatment ability of $M$. aquaticum is significantly enhanced by frequent harvesting (at least annually) (Nuttall, 1985) and we can partially repeat the considerations already expressed for $P$. australis.

However, this type of management can alter the renaturation process and preclude the possibility for the NWS to reach the climax conditions. Moreover, it is not to neglect that the deposit of the dead plant residue onto the NWS bottom can contribute to the formation of new peat and so reversing the actual trend of subsidence (Gessner, 2000; Domisch et al., 2006) that constitutes a severe constraint for the agricultural use of the reclaimed area (Silvestri et al., 2017).

\section{Conclusions and implication for wetland management}

The conversion of drained peatlands to natural wetland resulted, under our experimental conditions, an operation quite easy and short to implement. Just few years after the flooding and the partial top soil removal, the restoration process seemed to be well underway as proved by the development of some floristic association typical of the surrounding palustrine areas. This fact confirmed that the status of peatlands was not as degraded as to prevent the spontaneous vegetation recolonization of the rewetted areas.

Although our experimental area (NWS) was not so widespread to be considered representative of the whole Massaciuccoli Lake catchment, was reasonable suppose that the main plant communities and associations able to colonize rewetted peatlands are those identified within the experimental area and that our results can be considered reliable for upscaling use.

In our experimental conditions, characterized by a large availability of nutrients and water Phragmites australis showed a remarkable biomass productivity and nutrients taken up. Although
M. aquaticum had lower performances, we have to consider, for both species, the contribution derived from the nutrient portion within the biomass yearly fallen on the bottom of the system.

To increase furthermore the nutrient abatement capability of NWS, we can act optimise the harvest strategy. Indeed, the annual harvesting can increase the amount of nutrients removed from the system thanks to removal of harvested annual production. At same time, frequent cutting can penalize the plant growth during the initial phases, limit the peat forming process, make trouble in the management of the harvest operations (necessity of draining area or use of machines able to work in flooded conditions) and cause disturbance to the biota.

For this reason, the management of NWS has to find a compromise able to meet different needs (multifunctional management).

\section{Acknowledgments}

Thanks are due to Fabio Taccini (Scuola Superiore Sant'Anna), Maikol Landucci and Mario Ghilarducci (Consorzio di Bonifica Toscana 1 Nord) who helped during vegetation sampling and to Ulrich Möbius and Katrin Bünger (Institute of Botany and Landscape Ecology, Greifswald University) for their support with laboratory analyses.

We expand our acknowledgment to Dr. Carmelo Di Franco, Dr. Alessandra Melani, Dr. Mauro Marinoni and Prof. Giorgio Buttazzo who programmed the drone for the required task of vegetation monitoring and piloted in the experimental area and provided support during the paper revision.

This work was supported by the "Consorzio di Bonifica VersiliaMassaciuccoli" later "Consorzio di Bonifica 1 Toscana Nord" and funded by the "Regione Toscana".

\section{References}

Asaeda, T. Hietz, P. Tanaka, N., Karunaratne, S., 2002. Seasonal fluctuations in live and dead biomass of Phragmites australis as described by a growth and decomposition model: implications of duration of aerobic conditions for litter mineralization and sedimentation. Aquat. Bot. 73 (3), 223-239.

Asaeda, T., Rajapakse, L., Manatunge, J., Sahara, N., 2006. The effect of summer harvesting of Phragmites australis on growth characteristics and rhizome resource storage. Hydrobiologia 553 (1), 327-335.

Bertacchi, A., Lombardi, T., Giannini, V., Silvestri, N., Bonari, E., 2015. A case of ecological renaturation in a drained mediterranean peatland: the case study of the Massaciuccoli lake basin (Tuscany, It). In: $110^{\circ}$ Congresso Della Società Botanica Italiana Onlus. II International Plant Science Conference (IPSC). "Not Only Food: Sustainable Development, Agro-biodiversity Conservation \& Human Well Being" Pavia, pp. 14-17. September 2015.

Bonari, E., Ercoli, L., Silvestri, N., 2013. Introduzione al progetto e sintesi interpretativa. In: Agricoltura e tutela delle acque nel bacino del lago di Massaciuccoli. Pacini Editore, Pisa (IT), pp. 27-37.

Braun-Blanquet, J., 1979. Fitosociologia. Bases para el estudio de las comunidades vegetales, vol. 1, p. 819

Conti, F., Abbate, G. Alessandrini, A., Blasi, C., 2005. An Annotated Checklist of the Italian Vascular Flora. Ministero dell'Ambiente e della Tutela del Territorio, Direzione per la Protezione della Natura. Palombi ed.

Couwenberg, J., Thiele, A., Tanneberger, F., Augustin, J., Barisch, S., Dubovik, D., Joosten, H., 2011. Assessing greenhouse gas emissions from peatlands using vegetation as a proxy. Hydrobiologia 674 (1), 67-89.

DIN EN 14961-1, 2010. Solid Biofuels - Fuel Specifications and Classes -Part1: General Requirements. Beuth Verlag, Berlin.

DIN EN 15104, 2010. Solid Biofuels - Determination of Total Content of Carbon, Hydrogen and Nitrogen - Instrumental Methods. Beuth Verlag, Berlin.

Domisch, T., Finér, L., Laine, J., Laiho, R., 2006. Decomposition and nitrogen dynamics of litter in peat soils from two climatic regions under different temperature regimes. Eur. J. Soil Biol. 42 (2), 74-81.

Eid, E.M., Shaltout, K.H., Al-Sodany, Y.M., Soetaert, K., Jensen, K., 2010. Modeling growth, carbon allocation and nutrient budgets of Phragmites australis in Lake Burullus, Egypt. Wetlands 30 (2), 240-251.

Findlay, S.E., Dye, S., Kuehn, K.A., 2002. Microbial growth and nitrogen retention in litter of Phragmites australis compared to Typha angustifolia. Wetlands 22 (3), 616-625

Gessner, M.O., 2000. Breakdown and nutrient dynamics of submerged Phragmites shoots in the littoral zone of a temperate hardwater lake. Aquat. Bot. 66 (1), 9-20. 
Giannini, V., Oehmke, C., Silvestri, N., Wichtmann, W., Dragoni, F., Bonari, E., 2016 Combustibility of biomass from perennial crops cultivated on a rewetted Mediterranean peatland. Ecol. Eng. 97, 157-169.

Giannini, V., Silvestri, N., Dragoni, F., Pistocchi, C., Sabbatini, T., Bonari, E., 2017. Growth and nutrient uptake of perennial crops in a paludicultural approach in a drained Mediterranean peatland. Ecol. Eng. 107, 478-487.

Gopal, B., Sharma, K.P., 1982. Studies of wetlands in India with emphasis on structure, primary production and management. Aquat. Bot. 12, 81-91.

Granéli, W., 1984. Reed Phragmites australis (Cav.) Trin. ex Steudel as an energy source in Sweden. Biomass 4 (3), 183-208.

Granèli, W., 1989. Influence of standing litter on shoot production in reed, Phragmites australis (Cav.) Trin. ex Steudel. Aquat. Bot. 35, 99-109.

Granéli, W., 1990. Standing crop and mineral content of reed, Phragmites australis (Cav.) Trin. Ex Steudel, in Sweden-management of reed stands to maximize harvestable biomass. Folia Geobot. Phytotaxonomica 25 (3), 291-302.

Grootjans, A.P., Van Diggelen, R., Joosten, H., Smolders, A.J., van Andel, J., Aronson, J., 2012. Restoration of Mires. Restoration Ecology: the New Frontier, second ed., pp. 203-213

Güsewell, S., Le Nedic, C., Buttler, A., 2000. Dynamics of common reed (Phragmites australis Trin.) in Swiss fens with different management. Wetl. Ecol. Manag. 8 375-389.

Hocking, P.J., 1989. Seasonal dynamics of production, and nutrient accumulation and cycling by Phragmites australis (Cav.) Trin. Ex Steuedel in a nutrientenriched swamp in inland Australia. I Whole plants. Aust. J. Mar. Freshw. Res. 40, 421-444.

Hussner, A., Meyer, C., Busch, J., 2008. The influence of water level and nutrient availability on growth and root system development of Myriophyllum aquaticum. Weed Res. 49, 73-80.

Joosten, J.H.J., 1995. Time to regenerate: long-term perspectives of raised bog regeneration with special emphasis on paleoecological studies. In: Wheeler, B.D., Shaw, S.C., Fojt, W.J., Robertson, R.A. (Eds.), Restoration of Temperate Wetlands. John Wiley \& Sons, Chichester, New York, Brisbane, Toronto, Singapore, pp. 471-494.

Karunaratne, S., Asaeda, T., Yutani, K., 2003. Growth performance of Phragmites australis in Japan: influence of geographic gradient. Environ. Exp. Bot. 50 (1), $51-66$.

Klančnik, K., Zelnik, I., Gnezda, P., Gaberščik, A., 2015. Do reflectance Spectra of different plant stands in wetland indicate species properties?. In: The Role of Natural and Constructed Wetlands in Nutrient Cycling and Retention on the Landscape. Springer International Publishing, pp. 73-86.

Klimkowska, A. Kotowski, W. van Diggelen, R. Grootjans, A.P., Dzierza, P., Brzezinska, K., 2010a. Vegetation Re-development after fen meadow restoration by topsoil removal and hay transfer. Restor. Ecol. 18, 924-933.

Klimkowska, A., Van Diggelen, R., Grootjans, A.P., Kotowski, W., 2010b. Prospects for fen meadow restoration on severely degraded fens. Perspect. Plant Ecol. Evol. Systemat. 12, 245-255.

Kottek, M., Grieser, J., Beck, C., Rudolf, B., Rubel, F., 2006. World map of the KöppenGeiger climate classification updated. Meteorol. Z. 15 (3), 259-263.

Lamers, L.P.M., Smolders, A.J.P., Roelofs, J.G.M., 2002. The restoration of fens in The Netherlands. Hydrobiologia 478, 107-130.

Lamers, L.P.M., Vile, M.A., Grootjans, A.P., Acreman, M.C., van Diggelen, R., Evans, M.G., Richardson, C.J., Rochefort, L., Kooijman, A.M:, Roelofs, J.G.M., Smolders, A.J.P. (2015). Ecological restoration of rich fens in Europe and North-America: from trial and error to an evidence-based approach 90(1): 182-203.

Lastrucci, L., Foggi, B., Becattini, R., 2005. Myriophyllum aquaticum (Vell.) Verdc. (Haloragaceae): una nuova specie esotica invasiva per la Toscana. Informatore Botanico Italiano 37 (2), 1133-1136.

Lepš, J., 1999. Nutrient status, disturbance and competition: an experimental test of relationships in a wet meadow. J. Veg. Sci. 10 (2), 219-230.

Meissner, R., Leinweber, P., Rupp, H., Shenker, M., Litaor, M.I., Robinson, S., Schlichting, A., Koehn, J., 2008. Mitigation of diffuse phosphorus pollution during rewetting of fen peat soils: a trans-European case study. Water Air Soil Pollut. 188, 111-126.

Meyerson, L.A., Vogt, K.A., Chambers, R.M., 2002. Linking the success of Phragmites to the alteration of ecosystem nutrient cycles. In: Concepts and Controversies in Tidal Marsh Ecology. Springer, Netherlands, pp. 827-844.

Monteiro, A., Moriera, I., 1990. Chemical control of parrotfeather (Myriophyllum aquaticum). In: Proceedings of the 8th International Symposium on Aquatic Weeds, Uppsala, Sweden, 13-17 August 1990. European Weed Research Society, pp. $163-164$

Murphy, J., Riley, J.P., 1962. A modified single solution method for the determination of phosphate in natural waters. Anal. Chim. Acta 27, 31-36.

Nuttall, P.M., 1985. Uptake of phosphorus and nitrogen by Myriophyllum aquaticum (Velloza) Verd. Growing in a wastewater treatment system. Mar. Freshw. Res. 36 (4), 493-507.

Oleszczuk, R., Regina, K., Szajdak, L., Hoper, H., Maryganova, V., 2008. Impacts of agricultural utilization of peat soils on the greenhouse gas balance. In: Strack, M. (Ed.), Peatlands and Climate Change. International Peat Society, Jyvaskyla, Finland, pp. 70-98.

Pellegrino, E., Bosco, S., Ciccolini, V., Pistocchi, C., Sabbatini, T., Silvestri, N.,
Bonari, E., 2015. Agricultural abandonment in Mediterranean reclaimed peaty soils: long-term effects on soil chemical properties, arbuscular mycorrhizas and CO 2 flux. Agric. Ecosyst. Environ. 199, 164-175.

Pensabene, G., Frascari, F., Cini, C., 1997. Valutazione quantitativa del carico di nutrienti e di solidi sospesi immesso nel lago di Massaciuccoli dai comprensori di bonifica di Vecchiano e Massaciuccoli. In: Cenni, M. (Ed.), Lago di Massaciuccoli. 13 ricerche finalizzate. Editrice Universitaria Litografia Felici, Pisa (IT), pp. $131-147$.

Pfadenhauer, J., Grootjans, A.P., 1999. Wetland restoration in Central Europe: aims and methods. Appl. Veg. Sci. 2, 95-106.

Pignatti, S., 1982. Flora d'Italia, vol. 3. Edagricole, Bologna.

Pistocchi, C., Silvestri, N., Rossetto, R., Sabbatini, T., Guidi, M., Baneschi, I., Bonari, E.D., Trevisan, D., 2012. A simple model to assess nitrogen and phosphorus contamination in ungauged surface drainage networks: application to the Massaciuccoli Lake Catchment, Italy. J. Environ. Qual. 41 (2), 544-553.

Poschlod, P., 1992. Development of vegetation in peat-mined areas in some bogs in the foothills of the Alps. In: Bragg, O.M., Hume, P.D., Ingram, H.A.P., Robertson, R.A. (Eds.), Peatland Ecosystems and Man: an Impact Assessment. Department of Biological Sciences, University of Dundee and International Peat Society, pp. 287-290.

Podani, J., 2001. Syn-tax 2000. Computer Program for Data Analysis in Ecology and Systematics. Scientia Publishing, Budapest.

Rolletschek, H., Rolletschek, A., Hartzendorf, T., Kohl, J.G., 2000. Physiological consequences of mowing and burning of Phragmites australis stands for rhizome ventilation and amino acid metabolism. Wetl. Ecol. Manag. 8, 425-433.

Shibayama, H., 1988. Ecology of aquatic weeds in creeks of the paddy growing area in the lower reaches of the Chikugo river. Bull. Kyushu Natl. Agric. Exp. Stat. 25 (1), $1-75$.

Silvestri, N., Giannini, V., Dragoni, F., Bonari, E., 2017. A Multi-adaptive framework for the crop choice in paludicultural cropping systems. Ital. J. Agron. 12, 69-76.

Smolders, A.J.P., Lamers, L.P.M., Lucassen, E.C.H.E.T., Van der Velde, G., Roelofs, J.G.M., 2006. Internal eutrophication: how it works and what to do about it-a review. Chem. Ecol. 22 (2), 93-111.

Stroh, P., Hughes, F., 2010. Practical Approaches to Wetland Monitoring: Guidelines for Landscape-scale Long-term Projects. Anglia Ruskin University, Cambridge.

Sytsma, M.D., Anderson, L.W.J., 1993. Biomass, nitrogen, and phosphorus allocation in parrotfeather (Myriophyllum aquaticum). J. Aquat. Plant Manag. 31, 244-248.

Tanneberger, F., Wichtmann, W., 2011. Carbon Credits from Peatland Rewetting Climate-biodiversity-land Use. Schweizerbart Science Publishers, Stuttgart, p. 223.

Tiemeyer, B., Frings, J., Kahle, P., Kohne, S., Lennartz, B., 2007. A comprehensive study of nutrient losses, soil properties and groundwater concentrations in a degraded peatland used as an intensive meadow -Implications for re-wetting. J. Hydrol. 345, 80-101.

Thompson, D.J., Shay, J.M., 1985. The effects of fire on Phragmites australis in the delta Marsh, Manitoba. Can. J. Bot. 63, 1964-1869.

Tomei, P.E., Guazzi, E., Barsanti, A., 1997. La carta della vegetazione delle paludi e del Lago di Massaciuccoli. In: Lago di Massaciuccoli. 13 Ricerche finalizzate al risanamento. $2^{\circ}$ contributo. Lo stato delle conoscenze all'avvio delle opere di recupero ambientale. A cura di Mario Cenni. Ente Parco Migliarino San Rossore e Massaciuccoli. Felici Editore, Pisa, pp. 275-288.

Van Dijk, J., Stroetenga, M., van Bodegom, P.M., Aerts, R., 2007. The contribution of rewetting to vegetation restoration of degraded peat meadows. Appl. Veg. Sci. $10,315-324$.

Verhoeven, J.T.A., 2014. Wetlands in Europe: perspective for restoration of a lost paradise. Ecol. Eng. 66, 6-9.

Vymazal, J., 2007. Removal of nutrients in various types of constructed wetlands. Sci. Total Environ. 380 (1), 48-65.

Wersal, R.M., Madsen, J.D., 2011. Influences of water column nutrient loading on growth characteristics of the invasive aquatic macrophyte Myriophyllum aquaticum (Vell.) Verdc. Hydrobiologia 665 (1), 93-105.

WEPAL 2011. Certificate of Analysis BIMEP (International Biomass Exchange Program). Reference Material BIMEP Sample 412. Wageningen University of Environmental Sciences, Phragmites australis accessed at. http://www.wepal.nl/we bsite/download_files/consensus/BIMEP/BIMEP412.pdf. on January 6, 2016.

Wichtmann, W., Wichmann, S., 2011. Environmental, social and economic aspects of a sustainable biomass production. J Sustain Energy Environ Spec Issue 77-81.

Zak, D., Gelbrecht, J., 2007. The mobilisation of phosphorus, organic carbon and ammonium in the initial stage of fen rewetting (a case study from NE Germany). Biogeochemistry 85 (2), 141-151.

Zak, D., Gelbrecht, J., Steinberg, C.E.W., 2004. Phosphorus retention at the redox interface of peatlands adjacent to surface waters in northeast Germany. Biogeochemistry 70, 357-368.

Zak, D., Gelbrecht, J., Zerbe, S., Shatwell, T., Barth, M., Cabezas, A., Steffenhagen, P., 2014. How helophytes influence the phosphorus cycle in degraded inundated peat soils - implications for fen restoration. Ecol. Eng. 66, 82-90.

Zak, D., Meyer, N., Cabezas, A., Gelbrecht, J., Mauersberger, R., Tiemeyer, B., Wagner, C., McInnes, R., 2017. Topsoil removal to minimize internal eutrophication in rewetted peatlands and to protect downstream systems against phosphorus pollution: a case study from NE Germany. Ecol. Eng. 107, 488-496. 